\title{
Problems and Reforms in the Teaching and Practice of Visual Communication Design Major
}

\author{
Yuyang Zhang \\ Xi’an Peihua University, Xi’an, Shaanxi, 710125
}

Keywords: colleges and universities; visual communication design; teaching and practice

\begin{abstract}
The development of our country's economic level continues to promote the development of China's education industry, and the teaching level of the design major in colleges and universities is also rising. As an important branch of the design profession, visual communication has always had many problems in the integration of teaching and practice. Therefore, how to reform the teaching model of visual communication design from the perspective of practice and application of disciplines and improve its teaching quality and application level has become the common problem for education workers in the visual communication design in common colleges and universities.
\end{abstract}

\section{Introduction}

As China is now in an era of rapid development of science and technology and economy, design disciplines have continued to develop into a hot area with a high degree of integration with economy and aesthetics, and have become an indispensable part of modern market economy. Although China's ordinary colleges and universities already have relatively perfect visual communication design professional teaching system, but there is the problem of derailment from the market demand and operation, from the graduates of this professional when entering the workplace is often a blank, can not be effective Combine theory with practice. Therefore, how to establish an education model that meets the needs of market professionals is particularly important. This is also the change that must be made in the visual communication design profession in ordinary universities.

\section{The Visual Communication Design Education Model and the Status Quo}

The visual communication design major is a discipline that has gradually developed in China due to the continuous development of China's social and economic level and the continuous increase in social demand. The vigorous promotion of market demand in China has made the visual design communication profession always in a state of rapid development. Many universities and colleges in various parts of China have gradually built the education model and teaching system of visual communication design. However, the reason why many colleges and universities in China initially established this specialty was simply because this major can attract more students and more expensive tuition. However, this specialized teaching model has not been truly in-depth and scientifically explored. It has only blindly investigated the similar institutions. After the teaching mode, the school determined its own method of running schools. There are no clear plans and regulations for the purpose of teaching and the quality of the students to be achieved in their own schools. There is no special feature for running schools. However, due to its strong professional application, the visual communication design professional often requires a large amount of capital investment in the early stage to purchase equipment and facilities required for teaching. However, many colleges and universities started teaching this profession at a time when the teaching equipment was no different from other professions. It consisted of simple tables, chairs, and stools. Due to the shortage of professionals and teaching resources needed at the time, teachers were tired of dealing with a large group of teachers. This is a situation in which students who only read books will die. This is the mode of education when the visual communication design major of the ordinary colleges and universities in our country is initially set up. It can be imagined that the students 
educated under such education systems will inevitably have a considerable gap with the actual talent demand in society. Therefore, at the time, there was a general situation in the market that although the design industry and design companies in the market were highly eager for high-quality applied design talents, many design students who were trained in colleges and universities in our country did not have it. Form professional skills and face the "difficulty of employment" situation. For design enterprises to get the design graduates who are recruited to formally perform their duties, they must also receive a long-term employment training.

As a result, the needs of enterprises and students are not met, and the education market and job market for the visual communication design profession become correspondingly pros and cons. The situation can be seen everywhere. However, faced with this situation, educators in China's design profession have also been striving to find ways to improve the education system and solve such problems, and have achieved remarkable results. In recent years, the visual design communication professional in ordinary colleges and universities in China has also been continuously self-reform and self-improvement, in order to continuously achieve their own breakthroughs and improvements, and to cultivate applied design professionals as the goal, in the emphasis on students While cultivating theoretical knowledge, we also strive to enhance students' professional practice skills, and to develop both high-quality and applied design talents in China's market in a two-pronged manner. However, due to the introduction of this specialty from abroad, and in the process of improving and improving this professional teaching model and system in the later period, many educators still continue to learn from the European and American regional education model, which has caused these The teaching model of society and markets in Europe and the United States is derailed from the domestic market demand and social needs in China. Therefore, if the education workers in the visual communication design profession of China's ordinary universities cannot develop their own local characteristics and characteristics, the educational program will inevitably fail to develop localized talents that meet the needs of the Chinese market. Second, if it is an arts-professional college, because it does not have to consider the contradictions and particularities among various professions, it can largely follow the principles of running schools and methods of running schools of arts in Europe and the United States, but for our country Most of the ordinary colleges and universities, because of the particularity of the design profession, tend to have different degrees of conflict with other types of majors established in the school. Therefore, if ordinary colleges and universities directly follow the teaching model of art schools in Europe and the United States, it will inevitably produce more or less omissions and problems in its teaching practice.

\section{The Current Problems and Solutions of Visual Communication Design}

\subsection{Learning focus of ordinary college students}

Because visual communication design students in ordinary colleges and universities often consciously feel that their own schools have the resources and teaching level in the field of visual communication design, they are not as good as arts professional colleges. The measures taken are also very confused about their future employment direction.

However, although the visual communication design major in ordinary colleges and universities is indeed in teaching equipment support and teacher equipping, it is inferior to the arts professional colleges and universities, and they interact with the outside world in information and resources, as well as internship opportunities provided by schools. On the other hand, they cannot be compared with professional institutions. Therefore, the concerns of many visual communication design students in ordinary colleges and universities are not without reason. But from another point of view, the graduates of visual communication design majors in ordinary colleges and universities have different roles in the job market and the main positions they are applying for, that is, their The main competitiveness is not in the same area, so the focus of professional learning is also different. Currently, in the market of visual communication design in China, due to the increasingly refined division of jobs, different kinds of jobs are becoming more and more diverse, and different positions have different requirements for professional capabilities. Some of them are different. Emphasis on 
design performance, some focus on the content of design planning, while others focus on design materials, or on the aspects of post-processing, manual, etc., as well as design market liaison and information collection. With such a wide variety of job requirements, students of arts colleges and universities can't all be taken over. Moreover, with respect to the characteristics and key points of China's arts colleges and universities, they often focus on students' ability to design thinking and performance. As for the training of other markets, such as planning and communication, application of design materials and production of design techniques, and marketing, etc., the specialized arts colleges are less specialized in training. Therefore, if students in visual communication design majors in ordinary colleges and universities can develop more comprehensive and in-depth capabilities in the areas where these arts college students are not good at, they will certainly be able to make a difference in the job market and find satisfactory jobs.

Nowadays, many companies need more assistant class business talents in the design field. Therefore, visual communication design students in ordinary colleges and universities can focus their learning on these aspects, focusing on cultivating their talents in supporting business capabilities, and related The educators should also emphasize the proportion of application links in the professional teaching process in the setting of teaching syllabus and the orientation of teaching objectives, and continuously strengthen the professional application ability of visual communication students in ordinary universities, making them not only proficient in visual communication. The relevant principles of design can be more flexible and easier to manage in all aspects of the design process, including the process and technology.

In this way, not only can the employment pressures of visual communication design students in general colleges and universities be alleviated, but also the competition between them and the related professional graduates of arts colleges can be eased. At the same time, they can meet the needs of different companies and units in the design industry. Different needs of design talents. We have avoided the waste of resources between different types of colleges and universities in the same profession in China, and continue to urge China's visual communication design professional to develop in depth.

\subsection{College teaching is too ideal and often derails from practice}

Many of China's art institutions are often exposed to the most advanced and cutting-edge design projects and design information in the world because of their professionalism and pertinence, or their relatively developed regions. Relatively speaking, many domestic colleges and universities, often because of inadequate funding or relatively remote areas, their teaching models are often unable to communicate with international frontier information in a timely manner, and the contents of the design work assigned by teachers to students are often It is more idealistic and does not fully reflect the unpredictable needs of the business age. However, because the visual design communication majors of ordinary colleges and universities are all often categorized as a non-climate teaching unit in a certain faculty, the school's financial support and investment in this profession are well-known and insufficient to support this profession. Close to the domestic first-rate level, not to mention the international frontier. Therefore, students of visual design communication majors in ordinary colleges and universities are compared with students of art majors, many of which require large-budget projects such as lectures by well-known scholars and experts at home and abroad, exhibitions of the latest design works in the industry, and sibling colleges. The interaction between communication and information cannot be enjoyed. In this way, it is even more difficult to avoid the situation where the professional design and the actual market demand are derailed for a long time. It is because the professional information has not been updated and it has been given the vision of ordinary colleges and universities. Students who design a communication major cause great losses. On the other hand, if the visual communication design teachers of ordinary colleges and universities because of information lag, can not master the most advanced design technology at home and abroad, they will lead them to update teaching content and teaching knowledge in the course of teaching students. Therefore, students may have been learning some backward knowledge for a short period of time. It is well-known that the visual design 
communication professional cares most about its timeliness and innovation, which will undoubtedly make ordinary colleges and universities communicate their visual design. The competitiveness of professional students is greatly reduced.

This can be seen from the professional competitions in many domestic visual design and communication professions. Many students from domestic first-line art colleges located in developed regions are often compared to many ordinary college students in remote areas. They occupy the best resources and the best teachers, and can seize the opportunities in this field. Whether in design thinking or design performance, they must be far better than students from other universities in other parts of the country. The main reason for all this is because of the imbalance and inequality of resources between regions and between schools and schools. For these issues that seriously affect the development of China's visual communication design profession, the author believes that in addition to the national and regional schools and schools and the professional department itself attaches great importance, continue to increase investment, whether in the training of teachers, or in teaching equipment In terms of input, we must increase financial support and input so that the communication channels for professional information can be made more smooth. Only in this way can the professional college students continue to break through their own regional restrictions and obtain more resources that can keep pace with the times. . However, due to the uneven distribution of resources between regions, the gap between students in different regions is extremely wide. For example, students who study visual communication design in Beijing are able to participate in many international cutting-edge design projects with high-tech technology, thanks to the guidance of instructors with the most advanced resources and technologies. In terms of design depth, etc., they can comfortably manage these aspects of the content, and their design level is often more than a few steps higher than that of ordinary college students in other regions.

In addition, it is not difficult to find the best quality and most ideal design materials in a large city like Kitakasahiro. In terms of related production techniques and technologies, it is also possible to select the most advanced international technology. Learning in such an environment where resources are easily accessible and the market is highly convenient makes it difficult for students to remain interested in the design profession. But at the same time, in contrast to the students of visual design and communication design in ordinary universities in other regions of China, the demand for design products in the local market is not high, and the teachers' teaching ability is also mediocre. Therefore, their own professional requirements are also very low. , Designed products are often fisheyes. Therefore, if we want to change this situation, we must improve the requirements for professional students in the visual design of ordinary colleges and universities. On the other hand, we must combine the characteristics of the local area and take a unique road of design development. Combining local resources creates different possibilities. Strive to avoid weaknesses and give full play to the geographical advantages of each region. Develop students with local characteristics.

\section{References}

[1] Zhang Qiang. On the Problems and Reforms of Teaching and Practice of Visual Communication Design Specialty in Colleges and Universities[J]. Beauty and Times,2016(2):116-118.

[2] Lu Yiwen. New Ideas on Teaching Reform of Visual Communication Design Majors in Colleges and Universities [J]. New Curriculum Research X Journal, 2017(10): 118-119.

[3] Xiao Bing. Research and Practice of Talent Training Model for Visual Communication Design Professionals[J]. Arts Science and Technology,2016,29(2):40-42.

[4] Liu Yuan. Research on innovative ideas of the reform of visual communication design curriculum system[J]. Science and Technology Get Rich Wizard, 2013(21): 155-156.

[5] Cao Shu. Innovation and Reform of Applied Undergraduate Curriculum: Taking Visual Communication Design as an Example [J]. Modern Decorative Theory, 2016(10):111-112. 